\title{
Self-efficacy in Primary Schools Students as Potential Characters: From the Perspective of Students' Self-ability and Interest
}

\author{
Yeni Rakhmawati ${ }^{\bowtie 1}$ \& Ali Mustadi2 \\ 1 Postgraduate UNY, Yogyakarta State University, Sleman, Indonesia \\ 2 Lecture UNY, Yogyakarta State University, Sleman, Indonesia \\ $\bowtie$ yenirakhmawati247.2017@student.uny.ac.id
}

\begin{abstract}
Self-efficacy has an important role to strengthen one's belief in completing tasks. This research focused on the lack of self-efficacy in primary school students. The purpose of this research is to describe the potentials and urgency of self-efficacy seen from the perspective of students' self-abilities and interests in the fifth-grade of primary school students. The subjects of this research were 108 students and 14 teachers in primary schools that implemented the 2013 Curriculum in Seyegan Sub-district, Sleman, Yogyakarta. The object of this research was the response to self-efficacy. Moreover, a descriptive quantitative approach was adopted as the research method. The research instruments were questionnaires and open interview guidelines. Data collection technique used was a non-test method using questionnaire and open interview guidelines. The findings revealed that: [1] students in the fifth-grade of primary schools had started to show self-efficacy; [2] students were able to value themselves; [3] self-efficacy could develop into potential characters. Students' selfefficacy was able to be developed starting from primary schools.
\end{abstract}

Keywords: potential character, primary schools, self-efficacy.

How to Cite: Rakhmawati, Y., \& Mustadi, A. (2019). Self-efficacy in Primary Schools Students as Potential Characters: From the Perspective of Students' Self-ability and Interest. Mimbar Sekolah Dasar, 6(1), 55-67. doi:http://dx.doi.org/10.17509/mimbar-sd.v6i1.15221.

INTRODUCTION Nowadays, individuals in the era of competitions use their critical thinking skills to find solutions. Characters are considered as the most influential basic in driving the individual. Character building and improvement of human resources can be achieved through education. Education is a place to develop an individual's interests and talent in developing skills and characters.

Programme International Student Assessment (PISA) is one of the standards for assessing global education. PISA assesses the abilities in science, mathematics, and reading for 15-year-old students every 3 years in 70 countries as the sample. In 2015, Indonesia was ranked 62, 63, and 64 from 70 countries in the competencies of science, math, and reading (OECD: 2015). Indonesia's rank was at the level two down (reproduction stage), in which students were not familiar with reasoning, argumentation, communication, rationale, and solving skills.

One of the factors causing Indonesia's low rank was the large number of students who dropped out of schools. Based on the statistical data of students in 2016/2017 Academic Year from Kemendikbud (2017), 
Yeni Rakhmawati \& Ali Mustadi, Self-efficacy in Primary Schools Students as Potential Characters...

from 25,618,078 students in primary school level, 4,400,553 students graduated, and 964,450 students or $21.92 \%$ of them did not continue to junior high school (SMP, Sekolah Menengah Pertama). Moreover, 39,213 or $0.15 \%$ of students dropped out of primary school.

In addition, there were $84 \%$ of Indonesia children who experience school violence (ICRW - International Center for Research on Women in Qodar, 2015). This finding contradicts the aims of the Millennium Development Goals (MDGs), which provide optimal and broadest education services for everyone (Masino \& Niñozarazúa, 2015). Education services in Indonesia have not been proven to completely fulfil the students' needs.

The government began to re-organize by starting from primary education. In this stage, factors that support the children learning needs include: teachers who graduate in education major that understand the needs of children, and the skills to manage classes (Irvine, Jim, \& Christhoper, 2010: 11-13); a healthy, clean, and safe environment that can protect children (Rwandan, 2009: 21-27); and meaningful and conducive learning activities (Widodo, 2017:13).

Education in Indonesia applies the 2013 Curriculum that prepares Indonesian students' character building. School activities facilitate the development of students' characters and social skills (Ummah \& Mustadi, 2018: 280). There are several programs that support the development of students' characters in Indonesia including child-friendly schools as school services, which are suitable for the students' needs by providing comfort and hope for students (Utami, Saputri, \& Kartikasari: 2017); and a religion-based curriculum in education level to reach the best character (Künkler \& Lerner: 2016). These programs aim at students' character reinforcement services.

Characters are the main learning objective for current education. Character building in primary school age is very necessary as the basis and foundation for children in building identities (Mustadi, 2011: 16). One of the characters that students must possess is self-efficacy. Selfefficacy is an idea based on a socialcognitive theory related to success beliefs of completing specific tasks (Bandura, 2009: 5). The social-cognitive theory is a theory that adds cognitive factors, such as beliefs, self-perception, and expectation to the social learning theory (Woolfolk: 2009); and the individual comprehensions in constructing and interpreting the meaning personally (Lawrence, Cervone, \& John, 2010: 434).

The individual's self-efficacy has an effect on self-confidence and expectation of results that lead to behavior and persistence. In accordance with Eller, Lev, Yuan, \& Watkins (2016: 3), self-efficacy refers to self-confidence to take action at a specific level. Self-efficacy is self-beliefs towards the abilities and competencies in 
performing given tasks, achieving goals, and overcoming obstacles (Arslan \& Yavuz: 2012). These explanations show that the individual with high self-efficacy has the ability to complete tasks and overcome obstacles in achieving the goals.

Self-efficacy is considered as an interesting topic to be examined because it has an important role for students' learning outcomes. This research shows its novelty since it is conducted at the primary school level in which the students have started to recognize their talent. Research of selfefficacy on the subject of the primary school age is still relatively rare. Selfefficacy is commonly examined at the level of further education, for instance, the research of the relationship between selfefficacy and cheating on high school students (Kusrieni: 2015). The results revealed that students with low selfefficacy were vulnerable to cheating behavior. Moreover, there were research of self-efficacy condition on higher education students (Wijaya \& Pratitis: 2012); (Rozali: 2015). Their research revealed the description of higher education students' self-efficacy during their period of study which showed that the students needed self-efficacy to adapt to the campus environment.

The subjects often used in the research of self-efficacy are adults who have worked. Self-efficacy has a close relationship to individual performance results, e.g. in the research on teachers' self-efficacy (Arslan
\& Yavuz: 2012). Teachers have to understand the level of students' selfefficacy in order to help students in learning. Students who are encouraged by teachers tend to have high self-efficacy. On the contrary, several research revealed that the individual with self-efficacy has characteristics as follows: 1) are able to complete task: 2) are confident: 3) are able to work independently: 4) are able to decide things according to their interests: 5) enjoy challenges: 6) are target oriented.

Based on the above research results, the indicators have appeared in primary school age children. Sutirna (2013) adds that children aged 9-10 years old (fifthgrade of primary school) start to have a desire to develop themselves in various ways that support their abilities. Students nowadays have mastered reading, writing, and mathematical skills. They begin to choose their preferred subjects and understand their interests and talents.

Self-efficacy is one of the individual characters related to the aspects of positive self-understanding. Self-efficacy is a cognitive structure to form learning experiences based on beliefs to complete tasks (Sullivan \& Mahalik: 2010). Selfefficacy is considered as selfreinforcement. The importance of selfefficacy is a key action (Mukhid, 2009: 118), the assessment of their own abilities (King: 2010), and the assessment of the individual regarding their own abilities to carry out certain behaviors (Ghufron \& Risnawati, 2012: 76). Self-efficacy affects 
Yeni Rakhmawati \& Ali Mustadi, Self-efficacy in Primary Schools Students as Potential Characters...

the individual in determining the action to be taken in order to achieve the objectives including an estimate of various events that will be encountered when completing tasks.

The difficulties faced by learners in gaining academic skills are directly related to beliefs that they are unable to learn or follow the learning (Sadewi, Sugiharto, \& Nusantoro, 2012: 11). Therefore, it can be concluded that learners mostly have difficulties in learning not because they are actually unable to work successfully, but because they believe that they are unable to work successfully.

This research aims at describing: 1) selfefficacy of primary school students in the fifth-grade: 2) that students possess selfefficacy starting from an early age: 3) potential self-efficacy that can develop into dominant characters.

\section{METHODS}

\section{Research Methods}

This research used the quantitative descriptive method to analyze the research data in the form of numbers, thus it can provide regular and clear descriptions of the conditions that can be used to draw meaning (Ananda \& Fadhli, 2018: 28). This research was intended to explain the description of primary school students' self-efficacy in fifth-grade students. This research was conducted in public primary schools that applied the 2013 Curriculum and with "A" accreditation in Seyegan Sub-district,
Sleman District in the 2017/2018 Academic Year, and carried out in OctoberNovember 2018.

\section{Research Subjects}

The subject of this research were 108 fifthgrade students and 14 fifth-grade teachers of public primary schools that applied the 2013 Curriculum and with "A" accreditation in Seyegan Sub-district, Sleman District in the 2017/2018 Academic Year.

\section{Research Instruments}

To collect the data, the research instruments were a teacher questionnaire, a student questionnaire, and teacher interview. The questionnaires consisted of indicators of assessment of self-efficacy and the responses were calculated in the form of scores. Meanwhile, the interview as the secondary data was used to support the questionnaire data in describing the research data (Ananda \& Fadhli, 2018: 2831). The instruments on student and teacher questionnaires were developed based on indicators of self-efficacy proposed by Legowo, Yuwono, Rustam (2010). The student questionnaire rating scale used a Likert scale of 1-3 (poor $=1$, fair $=2$, and good $=3$ ) on 5 questions, and 3 questions were subjective answer choices. The teacher questionnaires rating scale also used a Likert scale of 1-3. The interview with the teachers was used to support the data from the questionnaires. 


\section{Data Analysis}

The data were analyzed using descriptive statistics. Descriptive statistics expresses and interprets data through the parameters of mean, median, mode, and frequency distribution. This analysis was not used to find causality, but instead to describe the data that have been categorized, presented, and/or arranged into a diagram (Ananda \& Fadhli, 2018: 28).

\section{RESULTS}

\section{Student Results}

The student questionnaires consisted of eight questions, five of which used Likert scale and three of which were closed questions. These questions were adjusted to the indicators of students' self-efficacy in the fifth-grade. Validation of questions 15 was assessed using the SPSS program and is presented in Table 1.

Table 1. Item Validity.

\begin{tabular}{lllll}
\hline Aspect(s) & N & $\begin{array}{l}\text { Corrected ltem-Total } \\
\text { Correlation }\end{array}$ & Mean & Std. Deviation \\
\hline Comfort in learning & 108 & 0.230 & 2.888 & 0.315 \\
Autonomy in completing & 108 & 0.247 & 2.518 & 0.520 \\
assignments & 108 & 0.231 & 2.388 & 0.489 \\
Confidence in the abilities & 108 & 0.277 & 2.101 & 0.360 \\
Daring to give opinions & 108 & 0.161 & 2.277 & 0.449 \\
Socializing and grouping &
\end{tabular}

Note: the questionnaires were answered by 108 students.

The aspects of numbers 1-5 obtained the correlation result that was higher than the standard r-table with the value of 0.16 . All questions were above the value of 0.16 , thus it was concluded that the questions used were valid. The aim of assessing standard deviation was to find the homogenous data. Based on the data table, every question had the standard deviation that was larger than 0 . It indicated that the higher the standard deviation value, the higher the available diversity of samples. The data of selfabilities in students is presented in Table 2.

Table 2. The Aspects of Self-efficacy regarding self-abilities.

\begin{tabular}{llll}
\hline I. Self-ability & Poor & Fair & Good \\
\hline Comfort in learning & 0 & 12 & 96 \\
Autonomy in completing assignments & 1 & $(11.1 \%)$ & $(88.9 \%)$ \\
& $(0.9 \%)$ & 50 & 57 \\
Confidence in the abilities & 0 & $66.3 \%)$ & $(52.8 \%)$ \\
& & $(61.1 \%)$ & 42 \\
Daring to give opinions & 2 & 93 & $(38.9 \%)$ \\
& $(1.9 \%)$ & $(86.1 \%)$ & 13 \\
Socializing and grouping & 0 & 78 & $(12 \%)$ \\
& & $(72.2 \%)$ & 30 \\
\hline
\end{tabular}

Note: The questionnaires were answered by 108 students.

On the point of comfort in learning, students expressed that they really enjoyed learning activity in schools. Moreover, some activities in schools were 
Yeni Rakhmawati \& Ali Mustadi, Self-efficacy in Primary Schools Students as Potential Characters...

done independently, such as reading, doing assignments, and cleaning up the classroom. Even though students enjoyed learning and doing the activities independently in schools, their confidence in doing the assignments was still in the fair category. In addition, the point for expressing opinions and ideas was still in the fairly courageous category. Furthermore, the point for group socialization was in the fair category. The data of students' interest awareness is presented in Table 3.

Table 3. The Aspects of Self-efficacy regarding Interest Awareness.

\begin{tabular}{lll}
\hline II. Interest Awareness & Frequency & Percentage(s) \\
\hline Subject(s) based on the ability & & \\
\hline Mathematics & 55 & 51 \\
Science studies & 26 & 24 \\
Languages & 16 & 15 \\
Civic education & 9 & 8 \\
Social studies & 2 & 2 \\
\hline Preferred reading & \\
\hline Mathematics & 39 & 36 \\
Nature & 18 & 17 \\
Illustrations & 14 & 13 \\
All readings & 37 & 34 \\
\hline Interesting activities & & \\
\hline Group & 21 & 19 \\
Reading & 32 & 30 \\
Discussion & 55 & 51 \\
\hline Note: the questionnaires were answered by 108 students.
\end{tabular}

In the sixth question, namely choosing the preferred subject based on the students' ability, the students chose mathematics as the most preferred subject because they liked to count. Even though the difference in the number of students between science and language subjects was 10 students, their reasons for choosing those subjects were similar, since they thought that those subjects were easy to learn. Meanwhile, the students who chose civic education considered the subject related to the condition of Indonesia and the surrounding environment. On the other hand, the students did not choose social studies because the subject had a lot of materials and it was not interesting for them.
The seventh question was related to the type of preferred readings. One of the selfefficacy factors was to decide actions to help students in developing their abilities. Based on the results above, the students chose math readings as the most preferred reading.

The eighth question was related to the preferred students' activities. The students chose discussion as the preferred activity. However, their interest in the activity of expressing opinions (aspect number 4) was still in the fair category. Based on the fourth and eight questions, it can be concluded that the students enjoyed the discussion activity, either in groups or individually, yet they were less courageous in expressing their opinions. 


\section{Teacher Results}

The teacher questionnaires consisted of five questions related to child-friendly education and students' needs in selfefficacy. The questions were about 1) students' enthusiasm, 2) students' autonomy, 3) interest in learning, 4) childfriendly environment, and 5) students' guidance. In addition, questions 1-5 used a Likert scale of 1-3 (poor $=1$, fair $=2$, and good $=3$ ). The data of the teacher questionnaire could be seen in Table 4.

Table 4. The Result of Teacher Questionnaire.

\begin{tabular}{llllll}
\hline Question(s) & N & Fair & Good & Mean & Std. Deviation \\
\hline P1 & 14 & $\begin{array}{l}4 \\
(28.6 \%)\end{array}$ & $\begin{array}{l}10 \\
(71.4 \%)\end{array}$ & 2.71 & 0.468 \\
P2 & 14 & $\begin{array}{l}3 \\
(21.4 \%)\end{array}$ & $\begin{array}{l}11 \\
(78.6 \%)\end{array}$ & 2.78 & 0.425 \\
P3 & 14 & 0 & $\begin{array}{l}14 \\
(100 \%)\end{array}$ & 3.00 & 0.000 \\
P4 & 14 & $\begin{array}{l}6 \\
(42.9 \%)\end{array}$ & $\begin{array}{l}8 \\
(57.1 \%)\end{array}$ & 2.57 & 0.513 \\
P5 & 14 & $\begin{array}{l}1 \\
(7.1 \%)\end{array}$ & $\begin{array}{l}13 \\
(92.9 \%)\end{array}$ & 2.92 & 0.267 \\
\hline
\end{tabular}

Note: The questionnaire answered by 14 teachers.

None of the teachers answered 'poor' in the questionnaire. In the first question, students' enthusiasm in learning was in the fair category. This was in line with the result of the second question showing that students had the autonomy to carry out the activities in schools. Moreover, the absolute score was obtained in the third question, namely all teachers revealed that students' learning interest had been achieved. A similar result was obtained in the fourth question in which the childfriendly education had not been well implemented. Meanwhile, in the fifth question related to counselling for students, the teachers responded that it had been implemented.

The questionnaire data was supported by the result of open interviews with three teachers of the fifth-grade, and two school principals, which was conducted on
November, $5^{\text {th }}-9^{\text {th }} 2018$. The result of the interviews were: 1) students' autonomy was built through teacher motivation; 2) classrooms' atmosphere helped students in learning; 3) group activities helped students to give opinions; 4) students were less confident in doing tasks, especially when working on tests; 5) some students still did not have learning goals, thus they went to school only to play and to meet their friends; and 6) child-friendly environment was very helpful for students' mental development.

\section{DISCUSSION}

Self-Efficacy of Primary School Students in Fifth-grade

The characteristics of the fifth-grade primary school students were that they enjoyed learning and playing, and had a desire to start developing their talents. Based on the research results, the fifth- 
Yeni Rakhmawati \& Ali Mustadi, Self-efficacy in Primary Schools Students as Potential Characters...

grade primary school students enjoyed the activities that involved peers, thus they could play with their friends. This was in line with Yusuf \& Sugandhi (2011: 12), which explained that in the development period in of children aged around 6 to 10 yearsoften called the primary school yearsone of the children's characters is that they enjoy playing.

The activities with peers were favored by students. This was illustrated by the fact that the students mostly chose group activities (point 5) and discussion (point 8) as the most preferred activities. However, the courage to express opinions (point 4) was in the fair category. The results indicated that although group activities were interesting, fifth-grade students considered that expressing ideas was not easy. They enjoyed socializing with peers to tell about their daily life, hobbies, and anything in their environment. However, when they expressed their opinions and ideas about learning subjects, students were not brave enough.

At that age, the students' mentality was developing and had a sense of comfort with the school environment and friends. It was proven by the result that $88.9 \%$ of the students enjoyed learning in schools (point 1). This was also supported by the teacher questionnaire revealing that $100 \%$ of the students had interest in learning in the school (point 3), and $71.4 \%$ of the students were enthusiastic in learning (point 1). This is in accordance with the research conducted by Az-zahra, Sarkadi, \&
Bachtiar (2018) on the primary school students in fifth-grade which showed that students possessed $34.1 \%$ ability skills, $12.6 \%$ social skills, $14.7 \%$ cooperative skills, and $38.5 \%$ moral values.

The similarity between their research and this research was that the students had basic capabilities and awareness of values in the community. The difference lied on the students' interest in socializing. In this research, the students enjoyed the activities related to group activities with peers. However, the previous research showed that social and cooperative skills were in the poor category compared with other skills.

The students' comfort in learning in the schools, socializing with peers, doing tasks, discussing, and carrying out activities independently were the characteristics of self-efficacy, that appeared in fifth-grade primary school students. At this stage, students had begun to understand selfaspect. According to Hergenhanh dan Olson (2013: 581), self-efficacy is selfconfidence that involves cognitive, social, and skills aspects that have to be organized in order to achieve goals. Based on the previous statement, the level of students' autonomy (point 2), confidence in self-competence (point 3), and courage to express opinions (point 4) of fifth-grade students in Seyegan Sub-district were still in the fair category.

Students' awareness to recognize and to try improving their ability had emerged. In 
choosing the preferred subjects (points 6), they chose Mathematics. Furthermore, Mathematics reading (point 7) obtained the highest score as the most preferred reading. Students chose Mathematics as a preferred subject and Mathematics reading to develop their interest. It indicated that students had realized learning needs and how to develop it. This research was in line with Hirst \& Tsai (2015: 3 ) in which self-efficacy had an effect to improve the students' creativity and confidence. The students were confident to determine their decisions that support their development.

According to the results, the characteristics of self-efficacy, that appeared in the students and that was in the high category, were interest in learning, autonomy, preference for group and social activities, preference for activities that support their abilities. Meanwhile, the characteristics in the poor category included the courage to express opinions, confidence in their abilities, and realizing their competencies.

\section{Urgency of Self-efficacy}

Self-efficacy played a role in encouraging students in doing activities, especially in carrying out tasks and achieving goals. The characteristics of the individual with high self-efficacy were confidence in determining the action when facing challenges, diligence and faith in the ability (Kusrieni, 2015: 108). On point 8, students chose the discussion activity as the most preferred activity. It indicated that the students already had the will and confidence to share their thoughts with friends. Through the discussion activity, the students could share information, and develop their interests.

The awareness to develop their abilities could be interpreted as the students' capacity to assess their ability. The students understood their needs and priorities that were important to them. Therefore, the students could carry out learning activities with responsibilities due to this awareness. This result was in line with the research conducted by Yang \& Ersanl (2015: 476) on junior high school students in which the students with high self-efficacy had more mature careers compared with other students with low self-efficacy. They could make choices that supported their career paths. They also worked more accurately than those who doubted their self-efficacy although they had the same abilities.

In addition, the students were active in carrying out activities independently (point 4) which indicated that they were confident in their ability to do the activity. This result was supported by the fact that $78.4 \%$ of the teacher's stated that the students had autonomy in doing learning activity (point 2). Students' autonomy in learning grew confidence in their abilities, so they did not depend on others. In line with this finding, Schunk \& Pajares (2002: 201) explained that the individual selfefficacy referred to confidence in the abilities to learn or to take action at a specific level. Self-efficacy was a key to 
Yeni Rakhmawati \& Ali Mustadi, Self-efficacy in Primary Schools Students as Potential Characters...

improving the evaluation of skills and abilities. Self-efficacy affected selected students learning strategies and students' steps in achieving their goals (Yusuf, 2011: 2624).

Based on the result of the questionnaires and previous research, self-efficacy had an important role in learning outcomes and activities. The students with high selfefficacy felt confident in learning, thus learning activities worked well, and it could support the students' learning outcomes.

\section{Self-Efficacy Developed into Potential Characters}

The fulfilment of adequate environments facilitates the development of selfefficacy. This finding showed that the high students' interest in learning was influenced by the comfort of learning environments and support from the teachers. In other words, self-efficacy could develop into a strong character in students. This result was in line with Elahi, Amrai, \& Javad (2011) who stated that self-efficacy could support the improvement of students learning and could eventually develop into a character for the individual. The creation of an environment that fulfilled the needs of the students could strengthen the characteristics of self-efficacy that had begun to appear in students. Therefore, the students could strengthen the potential self-efficacy in forming a strong character in themselves.
The next finding was students' autonomy and confidence that had begun to grow. The students' confidence made them try their best according to their abilities. The students' confidence in their abilities made them stay away from negative behavior, e.g. cheating. This result was in line with the research conducted by Kusrieni (2015: 111) about the relationship between selfefficacy and cheating behavior in which the result revealed that students with high self-efficacy had low cheating behavior.

The environment supported the reinforcement of students' character selfefficacy. Friendly schools provided comfort for the students in learning and developing their talents. Based on points 4 and 5 of the teacher questionnaire, the schools applied child-friendly environments and counselling services for the students. They would develop and not easily discouraged when they are comfortable. The students who were given counselling regularly could open themselves to their problems so that the teachers could help them solve their problems.

Based on the interview results, the teachers expressed that child-friendly education helped the children's mental development, thus the students had strong confidence and belief in their abilities. The students often had strong confidence in facing challenging tasks when they worked with their friends. The students' adjustment was affected by their selfefficacy, hence it affected behavior in socializing (Park \& Han, 2016: 67). 
Child-friendly education provided facilities for students to develop their self-efficacy. In accordance with Sutirna (2013), childfriendly education is the process for students to be passionate, enthusiastic, joyful, comfortable, and reassured in learning in the classroom. Therefore, they could obtain knowledge well, follow the learning comfortably, and feel safe, thus the students' needs for self-efficacy were fulfilled. The fulfillment of needs for selfefficacy in the supportive environment indicated that child-friendly education could be applied as a place for developing self-efficacy.

Self-efficacy in students truly needs to be developed. Moreover, self-efficacy is considered as a great potential for students. Self-efficacy drove the students' to move, aided them in determining the best decision for themselves, and supported them to be positive in facing the needs of the community. Self-efficacy became a potential character needed by the students to support them to struggle and compete with other individuals in the world.

Self-efficacy helped the students to complete tasks and achieve goals. Therefore, students obtained learning outcomes by developing their selfefficacy. The growth of students' selfefficacy was influenced by the social environment. The needs of students towards a sense of comfort could give confidence. Self-efficacy could be grown at an early age by applying child-friendly education in which it could provide a sense of comfort in learning. Teachers should be able to fulfil the students' needs to enhance self-efficacy. With selfefficacy, the students were responsible for their tasks and eventually obtained learning outcomes.

\section{CONCLUSION}

The research results showed that fifthgrade primary school students had shown the indicators of self-efficacy, including comfort in learning, autonomy, confidence, the courage to express an opinion, and group activities. These indicators appeared in accordance with the characteristics of being in cognitive development and being fond of playing. Students were able to understand their abilities and make decisions according to their needs. Self-efficacy helped students to obtain learning outcomes through the development of their self-efficacy. The growth in students' self-efficacy was influenced by social environments. The needs of students towards a sense of comfort could give confidence.

The following recommendation for further research can be observed from several weaknesses of this research. In terms of samples, the sample size is limited to one sub-district. Therefore, further research can apply a larger sample. In terms of research methods, this is descriptive research in which the results are the description of a condition. Further research can observe about the effect or relationship of selfefficacy and other variables. 
Yeni Rakhmawati \& Ali Mustadi, Self-efficacy in Primary Schools Students as Potential Characters...

\section{REFERENCES}

Ananda, Rusydi \& Fadhli, Muhammad. (2018). Statistik pendidikan (Teori dan praktik dalam pendidikan. Medan: Widya Puspita.

Arslan, C., \& Yavuz, G. (2012). WCES 2012 A study on mathematical literacy selfefficacy beliefs of prospective teachers. Procedia - Social and Behavioral Sciences, 46, 5622-5625. https://doi.org/10.1016/j.sbspro.2012.0 6.484 .

Az-zahra, H. R., Sarkadi, S., \& Bachtiar, I. G. (2018). Students' Social Literacy in their Daily Journal. Jurnal Mimbar Sekolah Dasar, 5(3), 162-173. https://doi.org/10.17509/mimbarsd.v5i3.12094.

Bandura, Albert. (2009). Self-efficacy in changing societies. Cambridge University Press.

Elahi, S., Amrai, K., \& Javad, M. (2011). The relationship between self-efficacy and academic achievement in high school students. Procedia - Social and Behavioral Sciences, 15, 765-768. https://doi.org/10.1016/j.sbspro.2011.0 3.180 .

Eller, L. S., Lev, E. L., Yuan, C., \& Watkins, A. V. (2016). Describing self-care selfefficacy: definitiion, measurement, outcomes, and implications. International Journal of Nursing Knowledge,0(0), 1-11.

Ghufron, MN \& Risnawita, R. (2012). Teoriteori psikologi. Yogyakarta: Ar-Ruzz Media.

Hergenhahn, BR \& Olson, M.H. (2013). An introduction of theories of learning, https://www.coursehero.com/, diakses 15 November 2018.

Hirst, G., \& Tsai, P. C. (2015). Exploitation and exploration climates ' influence on performance and creativity diminishing returns as function of selfefficacy. Journal Sagehub, XX(X), 122.

https://doi.org/10.1177/0149206315596 814.
Irvine, Jim \& Christopher. (2010). Final draft set of child friendly schools standards and indicators for teacher education. USA: UNICEF.

Kemendikbud. (2017). Ikhtisar data pendidikan tahun 2016/2017. Jakarta: Kementrian Pendidikan dan Kebudayaan.

King, Laura. (2010). Psikologi umum sebuah pandangan apresiatif. Jakarta: Salemba Humanika.

Künkler, M., \& Lerner, H. (2016). A private matter? Religious education and democracy in Indonesia and Israel. Britsh Journal of Religious Education, February 2016. https://doi.org/10.1080/01416200.2015. 1113933.

Kusrieni, Devi. (2015). Hubungan efikasi diri dengan perilaku mencontek. Jurnal Psikopedia: 2014. vol.3, no.2, hlm. 100111.

Lawrence A. Pervin, Daniel Cervone, Oliver P. Jhon. (2010). Psikologi Kepribadian Teori dan Pene-litian. (Terjemahan A. K. Anwar). Jakarta: Kencana (Edisi asli diterbitkan tahun 2004 oleh McGrawHill Company Inc.).

Legowo, V.A., Yuwono. S., \& Rustam, A. (2010). Correlation between selfefficacy and perception of leadership transformational style with job participation on the employess. Jurnal Psikohumanika, vol 3, 26-40.

Masino, S., \& Niño-zarazúa, M. (2015). WIDER Working Paper 2015 / 033 What works to improve the quality of student learning in developing countries? (March), UNU WIDER, 1-24.

Mukhid. (2009). Self-efficacy (perspektif teori kognitif sosial dan implikasinya terhadap pendidikan. Jurnal Tadris: .4, .1. . 107-122.

Mustadi, A. (2011). Pendidikan karakter berwawasan sosiokultural (sociocultural based character education) di sekolah dasar, daerah istimewa yogyakarta (DIY). Dinamika Pendidikan, (20), 1-15. 
OECD. (2015). Programme for international student assessment (PISA) result from PISA 2015 www.oecd.org.edu/pisa, diakses 15 November 2018.

Park, H., \& Han, M. (2016). The effects of social integration support programs in autonomous private, foreign language \& international high schools: focusing on changes in academic self-efficacy, self esteem, and career maturity. The Journal of Korean Education, 43 (2), 67-96.

Qodar, N. (2015). Survei ICRW : 84\% Anak Indonesia Alami Kekerasan di. Sekolah. (online).

Rozali, Y. A. (2015). Hubungan efikasi diri akademik dan dukungan sosial orang tua dengan penyesuaian diri akademik pada mahasiswa UEU Jakarta. Jurnal Psikologi, 13(1), 65-70.

Rwanda Ministry of Education. (2009). Child friendly schools infrastructure standards and guidelines. Republic Rwanda : Rwanda Ministry of Education.

Sadewi, A.I., Sugiharto, DYP., \& Nusantoro, E. (2012). Meningkatkan self efficacy pelajaran matematika melalui layanan penugasan konten teknik modeling simbolik. Jurnal Indonesian Journal of Guidance and Counseling: Theory and Application, vol 1, no. 2, hlm. 8-12.

Schunk, D. H., \& Pajares, F. (2002). The Development of academic selfefficacy. Development of Achievement Motivation, 1446, 15-31. https://doi.org/10.1016/B978-

012750053-9/50003-6.

Sullivan, K.R., and Mahalik, J. R. (2011). Increasing Career Self-Efficacy for Women: Evaluating a Group Intervention. American Counseling Association, no. 1, vol. 78, 54. Version of Record online : 23 Dec 2011.

Sutirna. (2013). Perkembangan dan Pertumbuhan Peserta Didik. Yogyakarta: ANDI OFFSET.

Ummah, R., \& Mustadi, A. (2018).
Developing reflective picture storybook media to improve students ' tolerance in elementary schools. Advances in Social Science, Education and Humanities Research, 173(Icei 2017), 280-283.

Utami, R.D., Saputri, M.K.D., \&Kartikasari, F.N. (2017). Implementasi Penerapan SekolahRamah Anak pada Penyelenggaraan Pendidikan Sekolah Dasar. The $5^{\text {th }}$ URECOL Proceeding. February 2017, Yogyakarta. Hal 170176.

Widodo, R. (2017). Sekolah ramah hak asasi manusia: solusi penghapusan pelanggaran HAM di sekolah. Jakarta: Komnas HAM.

Wijaya, I. P., \& Pratitis, N. T. (2012). Efikasi diri akademik, dukungan sosial orangtua dan penyesuaian diri mahasiswa dalam perkuliahan. Jurnal Persona, 117, 40-52.

Woolfolk, A. (2009). Educational psychology active learning edition: edisi kesepuluh bagian kedua. (Terjemahan Prajitno \& Mulyantini). Yogyakarta: Pustaka Pelajar. (Edisi asli diterbitkan tahun 2008 oleh Pearson Education Inc. Allyn and Bacon, 75 Arlington Street, Boston).

Yang, C., \& Ersanl, Õ. (2015). The relationship between students ' academic self-efficacy and language learning motivation: A study of 8th graders. Procedia - Social and Behavioral Sciences, 199, 472-478. https://doi.org/10.1016/j.sbspro.2015.0 7.534 .

Yusuf, M. (2011). The impact of selfefficacy, achievement motivation, and self- regulated learning strategies on students ' academic achievement. Procedia - Social and Behavioral Sciences, 15, 2623-2626. https://doi.org/10.1016/j.sbspro.2011.0 4.158.

Yusuf, S \& Sugandhi, N. M. (2011). Perkembangan peserta didik. Jakarta: PT Raja Grafindo Persada. 